\title{
A Tale of Two Revolutions: A Discourse Historical Analysis (DHA) of Selected Political Speeches during the Arab Spring of the Egyptian and Lebanese Revolutions
}

\section{Lubna Adel}

Assistant Professor, School of Linguistics and Translation, Badr University in Cairo (BUC), Egypt.

\begin{abstract}
Historians alone do not write history as the main contributor is the politician who reconstitutes political events via discourse. Discourse per se can be regarded as an argumentation scheme where the politician attempts to convince the masses of a standpoint or urge them to make a certain decision. The political discourse released during the Egyptian and the Lebanese Revolutions form arguments which demonstrate the role of politicians in writing history. The Discourse Historical Analysis (DHA) model by Reisigl and Wodak (2001) facilitates the investigation of selected speeches for the former Egyptian President, Mubarak, and the former Lebanese Prime Minister, Hariri, to examine the discursive strategies used by these politicians. The study also explores their fallacious arguments and the shared discursive patterns in writing the history of these two major events. The study concludes that Egyptian and Lebanese politicians rely on the fallacies of ad misericordiam, ad baculum, and ad verecundiam to construct the US/THEM dichotomy.
\end{abstract}

Keywords: Discourse Historical Analysis (DHA), revolution, discursive strategies, fallacies, \& US/THEM 


\subsection{Introduction}

Politics is a quest for power in which politicians address their nations during crisis to change how they think and act. Political discourse emerges when power or resistance is involved in a linguistic or non-linguistic activity (Chilton \& Schaffner, 1997). Beard (2000) adds that political discourse can be spoken or written. The protest waves of the Arab Spring which started in Tunisia in 2010 and expanded to the rest of the Arab world are crisis times for Arab politicians. The speeches released by the former Egyptian President, Hosni Mubarak, and the former Lebanese Prime Minister, Saad Hariri, during the Egyptian and Lebanese Revolutions entail arguments which blame their nations for the negative consequences of the situation. The persuasion scheme of their speeches brings Argumentation Theory to Critical Discourse Analysis (CDA) which make them worth exploration to uncover the construction of the positive self- and negative other-presentation. The analysis also highlights the shared discursive patterns between the Egyptian and the Lebanese politicians.

\subsection{Research Questions}

To reach the aforementioned objectives, the current study attempts to answer the following questions:

1. How are the people, events, and actions of these two Revolutions linguistically named in the selected speeches?

2. What characteristics, qualities, and features are attributed to the social actors of the speeches?

3. What are the topoi used by the politicians in the analyzed speeches?

4. To what extent do these topoi entail fallacies to construct a positive/negative image of the represented social actors?

The study employs the Discourse-Historical Analysis (DHA) model for Reisigl and Wodak (2001) to highlight the discursive strategies used in writing the history of these two revolutions. The nomination, predication, and argumentation strategies alone are examined to reveal the construction of the in-group and out-group.

\subsection{Theoretical Framework}

Language is a product of different spoken and written interactions which contributes to the development and formation of social practices. This notion is revealed in the tenets of Critical Discourse Analysis (CDA) which highlights the role of discourse in social life. CDA has three main approaches: Fairclough's Critical Language Study, van Dijk's Socio-Cognitive approach, and Wodak's Discourse-Historical Analysis (DHA). Critical Language Study is based on Critical Social Theory which gives priority to the social aspect of context, and the Socio-Cognitive approach stresses the socio-cognitive aspect of the discourse. Finally, Discourse-Historical Analysis views discourse from a historical context. Since the study employs DHA to analyze the selected speeches, the following section reviews its main tenants.

\subsection{Discourse-Historical Analysis (DHA)}

DHA is an interdisciplinary approach which stresses the historical perspective in interpreting a discourse. It goes beyond the linguistic dimension of discourse to encompass the historical, political, sociological, and/or psychological dimensions (Reisigl \& Wodak, 2001). Wodak (2001) adds that DHA examines historical and political texts and topics by integrating the knowledge about the historical sources and the background of the social and political fields where discursive events are embedded. 
In their analysis of discourses on racial, national, and ethnic issues, Reisigl and Wodak (2001) introduced five questions to define the strategies of self- and other-presentation. A strategy is the adopted plan of practices to reach a specific social, political, psychological, or linguistic aim. These questions resulted in five discursive strategies which construct the US/THEM dichotomy and the positive self- and negative other-presentation. The first is the referential or nomination strategies which construct social actors as in-groups and out-groups. Linguistically, they are realized through membership categorization devices and tropes. The predication strategies assign positive or negative attributes to social actors and is achieved through stereotypical evaluative attributions and positive/negative predicates. It is important to note that some referential strategies might have negative or positive connotations which make them fall under predication strategies.

The third strategy is argumentation which argues for or against a certain belief, concept, ideology, or action to justify the positive and negative attributes ascribed to the social actors. Wodak (2001) refers to the old, rhetorical notion of topos which is an argument based on shared opinions and stereotypes. Besides, perspectivation focuses on the degree of involvement of the speaker or the writer in the discourse and his/her stand (Wodak, 2001). It can be realized via reporting, describing, narrating, or quoting. Finally, the intensification and mitigation strategies modify the epistemic status of a proposition to reveal whether an argument is intensified or mitigated. The present paper focuses on the nomination, predication, and argumentation strategies to identify the fallacious arguments used by the Egyptian and Lebanese politicians in accounting for the Revolutions occurring in their countries.

\subsection{Methodology}

DHA studies the intertextual and interdiscursive relationships between texts and their extralinguistic and sociopolitical factors while considering the historical context. Reisigl and Wodak (2009) set a three-dimensional model to analyze discourse. It starts with the content which, according to Reisigl and Wodak (2001), entails the historical and political topics discussed in the discourse. The second level shows the discursive strategies, and the third clarifies the linguistic devices used to achieve the aim of discourse.

\subsection{DHA Model}

The discursive macro-strategies are constructive strategies which entail the overall aim(s) of the discourse topic. The current study focuses on three local discursive strategies: referential or nomination, predication, and argumentation, and their linguistic realization:
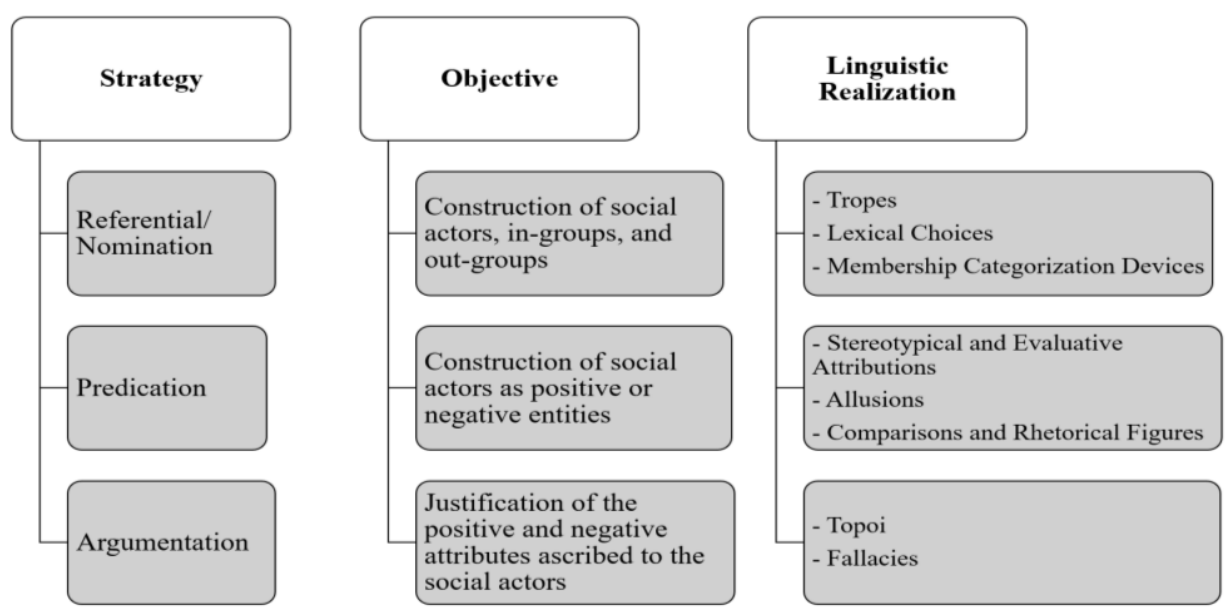

Figure (1): The analytical DHA model. Adapted from Reisigl and Wodak (2001), and Wodak et al. (2009). 
The referential/nomination strategies label persons, objects, phenomena, events, processes, and actions to construct the social actors of the discourse who are described using the predication strategies; the latter is concerned with the positive, negative, and neutral characteristics, qualities, and features attributed to the social actors. Finally, the argumentation strategies result from the predication strategies as they justify the attributes ascribed to the social actors.

The nomination/referential strategies are linguistically realized through tropes, lexical choices, and membership categorization devices. Wodak et al. (2009) state that tropes are discursive strategies used to create sameness between people; they include synecdoche, metonymy, and metaphor. Synecdoche is the act of naming within the same field of meaning; it occurs when the name of a referent is replaced by the name of another referent. Metonymy is a name used to refer to an entity. Finally, metaphors are implied comparisons between two unrelated entities which share a certain trait.

The lexical choices are recurrent in the nouns and verbs used to name the social actors of a certain discourse. Nouns, according to Wodak et al. (2009), can be concrete or abstract. Verbs are what constitute processes and actions which can be mental, verbal, and material. Finally, membership categorization devices classify the social actors involved in the discourse as in-group and out-group members to facilitate the creation of the US/THEM dichotomy. Wodak et al. (2009) highlight the use of anthroponyms which are names used to call people, events, phenomena, and objects such as personal references, quantifiers, and generic terms. They also add proper names, diectic expressions, spatial references, and temporal references.

Social actors gain their linguistic predication which labels social actors either positively or negatively. Wodak et al. (2009) emphasize attribution which is a quality or feature ascribed to the social actors as a linguistic realization. It includes adjectives, appositions, prepositional phrases, relative clauses, and stereotypes which embody negative and positive traits. Another linguistic tool is comparison which can be seen in the use of similes, comparatives, and superlatives. Lastly, allusions are indirect references to a certain event, person, or place through which the writer/speaker rely on the reader's background knowledge and familiarity with the topic (Wodak et al., 2009).

The positive self- and negative other-presentation established by the predication strategies requires justification. In this respect, Reisigl and Wodak (2001), Wodak (2006), and Wodak et al. (2009) introduce the notion of topoi where parts of an argument entail explicit or implicit premises. Topoi are connected through "the content related warrants or conclusion rules which connect the argument or arguments with the conclusion, the claim" (Reisigl \& Wodak, 2001, p. 74-5). The following figure illustrates the most common types of topoi employed in the study:

\begin{tabular}{|l|l|}
\hline Topos of Burdening & $\begin{array}{l}\text { - If X is burdened by a specific problem, he/she should diminish } \\
\text { the burden. }\end{array}$ \\
Topos of Numbers & $\begin{array}{l}\text { - When statistical evidence is given, a certain action should be } \\
\text { taken. }\end{array}$ \\
Topos of History & $\begin{array}{l}\text { History teaches people that certain actions have specific } \\
\text { consequences, and one should act based on the lessons learnt. }\end{array}$ \\
Topos of Authority & $\begin{array}{l}\text { The action becomes legitimate when there is a reference to an } \\
\text { authorial position. }\end{array}$ \\
\hline Topos of Threat and & $\begin{array}{l}\text { - One should do something whenever there is a threat or danger. } \\
\text { Danger }\end{array}$ \\
\hline Topos of Advantage & $\begin{array}{l}\text { If an action under a specific relevant point of view will be useful, } \\
\text { then one should perform it; it has } 2 \text { subtypes: advantage for Us } \\
\text { and advantage for all. }\end{array}$ \\
\hline
\end{tabular}

Figure (2): Most common topoi. Adapted from Reisigl and Wodak (2001), Wodak (2006), and Wodak (2009). 
Topoi are reasonable arguments, yet they become fallacious when they are not logical. The table below introduces the fallacies adopted in this study from Reisigl and Wodak (2001):

\begin{tabular}{|l|l|}
\hline $\begin{array}{c}\text { Argumentum ad } \\
\text { baculum }\end{array}$ & $\begin{array}{l}\text { - It is an attempt to threaten or intimidate the } \\
\text { listener/reader instead of using a logical argument }\end{array}$ \\
\begin{tabular}{|l|l|} 
Argumentum ad \\
hominem
\end{tabular} & $\begin{array}{l}\text { - It is an attack on the antagonist's personality and } \\
\text { character rather than the content of his/her argument. }\end{array}$ \\
\hline $\begin{array}{c}\text { Argumentum ad } \\
\text { misericordiam }\end{array}$ & $\begin{array}{l}\text { - It includes a justification based on compassion rather } \\
\text { than structured argument. }\end{array}$ \\
\hline $\begin{array}{c}\text { Argumentum ad } \\
\text { verecundiam }\end{array}$ & $\begin{array}{l}\text { - It occurs when the arguer supports his/her argument by } \\
\text { referring to authority. }\end{array}$ \\
\hline Straw man & - It is a misrepresentation of the antagonist's opinion. \\
\hline
\end{tabular}

Figure (3): Most Common fallacies. Adapted from Wodak and Reisigl (2001).

It is concluded from Figures (2) and (3) that a claim supported by a logical argument is a topos becomes fallacious when it is illogical.

\subsection{Data and Procedures}

The data analyzed in this study are selected speeches for the former Egyptian president, Hosni Mubarak, and the former Lebanese Prime Minister, Saad Hariri, after the wave of protests known as the "Arab Spring". The study examines two speeches for each politician to explore the shared discursive practices employed to account for these notable events. The study analyzes Mubarak's speeches, released in 2011 on January $28^{\text {th }}$ and February $10^{\text {th }}$. It also analyzes Hariri's speeches, released on October $18^{\text {th }}$ and October $28^{\text {th }}, 2019$. Even though Hariri's speeches occurred eight years after those of Mubarak's, the political situation is still the same as the speeches occurred within the Arab Spring framework. The speeches were delivered in Arabic, and the researcher transcribed them in their original language. The analysis begins with the political context to provide historical background on the circumstances of each speech, followed by the analysis of the three discursive strategies: nomination, predication, and argumentation.

\subsection{Analysis}

The European revolutions of the nineteenth century were known as "People Spring", and any movement or protest calling for democracy is described as "Spring". Hence, the protest waves occurring in the Arab world since 2010 are known as the "Arab Spring". The latter started in December 2010, in Tunisia, when the Tunisian street vendor, Muhammad Bouazizi, set himself on fire after the seizure of his vegetables. This action led to a wave of protests, known as the Jasmine Revolution. Its impact spread to numerous Arab countries such as Egypt, Libya, Bahrain, Syria, Yemen, and Lebanon. Some of these protests ended in toppling the ruling regime.

\subsection{Analysis of Mubarak's Speeches}

In Egypt, the protests started on the $25^{\text {th }}$ of January 2011 in Tahrir Square and lasted for 18 days. It called for "Bread, freedom, social justice". Hosni Mubarak dismissed his government and appointed a new cabinet and a vice president as a response to the protests. The escalation of the protests drove Mubarak to relinquish his powers to his Vice President, Omar Suleiman. Finally, Mubarak stepped down and transferred the power to the Egyptian Armed 
Forces. During this political crisis, Mubarak addressed the nation thrice: January $28^{\text {th }}$, February $1^{\text {st }}$, and February $10^{\text {th }}$. The analysis focuses on Mubarak's first and last speeches to trace his account of what the media called "Lotus Revolution".

\subsubsection{Analysis of Mubarak's Speech on January $28^{\text {th }}$}

The first time Mubarak addressed the nation on the Egyptian television was three days after the beginning of the protests on Friday, January $28^{\text {th }}, 2011$-known as "Friday of Anger". Mubarak stressed the protestors' right to express their opinion while respecting law and order. He also renewed his commitment to defend the stability and security of Egypt and announced the dismissal of the government and the formation of a new one. It is important to note that Mubarak uses the vocative "أيها الأخوة المواطنون" to move from one topic to another.

The nomination strategies of this speech classify the social actors into in-group and outgroup as illustrated in the following table:

Table 1

Social Actors of Mubarak's $1^{\text {st }}$ Speech

\begin{tabular}{|c|c|c|c|}
\hline $\begin{array}{l}\text { In-group Social } \\
\text { Actor }\end{array}$ & Linguistic Realization & $\begin{array}{l}\text { Out-group Social } \\
\text { Actor }\end{array}$ & Linguistic Realization \\
\hline Mubarak & 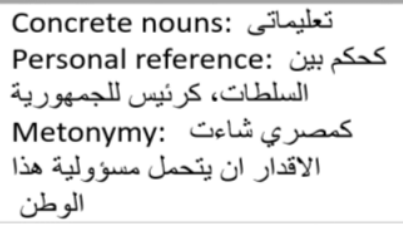 & Protest & 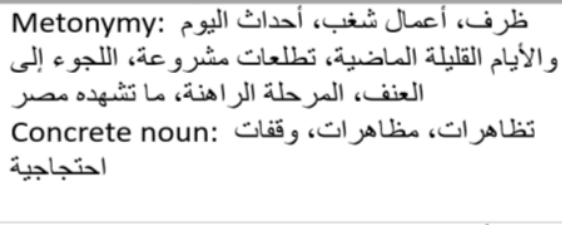 \\
\hline $\begin{array}{l}\text { Egyptian } \\
\text { Authorities }\end{array}$ & 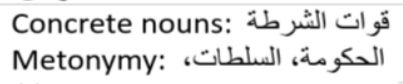 & Protestors & $\begin{array}{l}\text { Metonymy: أراء المواطنين، شبابنا، ضض البعضيا } \\
\text { Synecdoche }\end{array}$ \\
\hline & $\begin{array}{l}\text { الشر عية، : الدستور ، القانون } \\
\text { Abstract noun }\end{array}$ & The Nation & 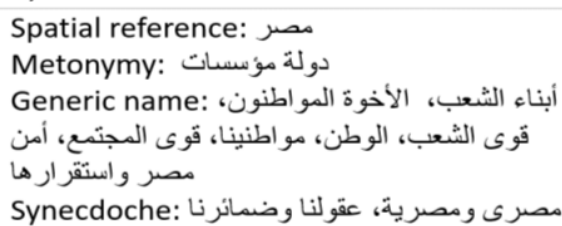 \\
\hline
\end{tabular}

The in-group social actors collaborate to resolve the crisis, and they are President Mubarak and the Egyptian authorities, namely, the police, cabinet, and the impersonal authorities of law and constitution. Mubarak stresses his authorial power by referring to his capacity as " كرئيس كمرى شاءت الأقدار أن “" When Mubarak refers to his nationality "كحكم بين السلطات" and "للجمهورية

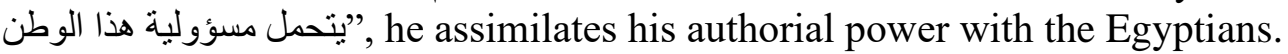

Moreover, there are direct and indirect references to the protestors and the protests as members of the out-group which bring the nomination and predication strategies together. The

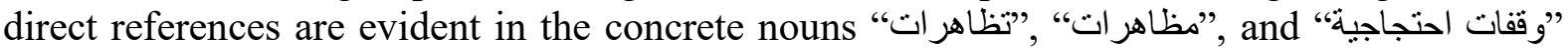
used for the protests. Metonymies are employed to abstain from the direct mentioning of the

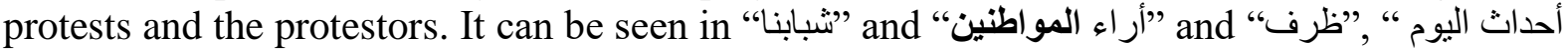
" in an attempt to present a neutral attribute for this out-group.

This is further supported by the lexical realization of the social actors as indicated in the table below: 
Table 2

Lexical Realization in Mubarak's First Speech.

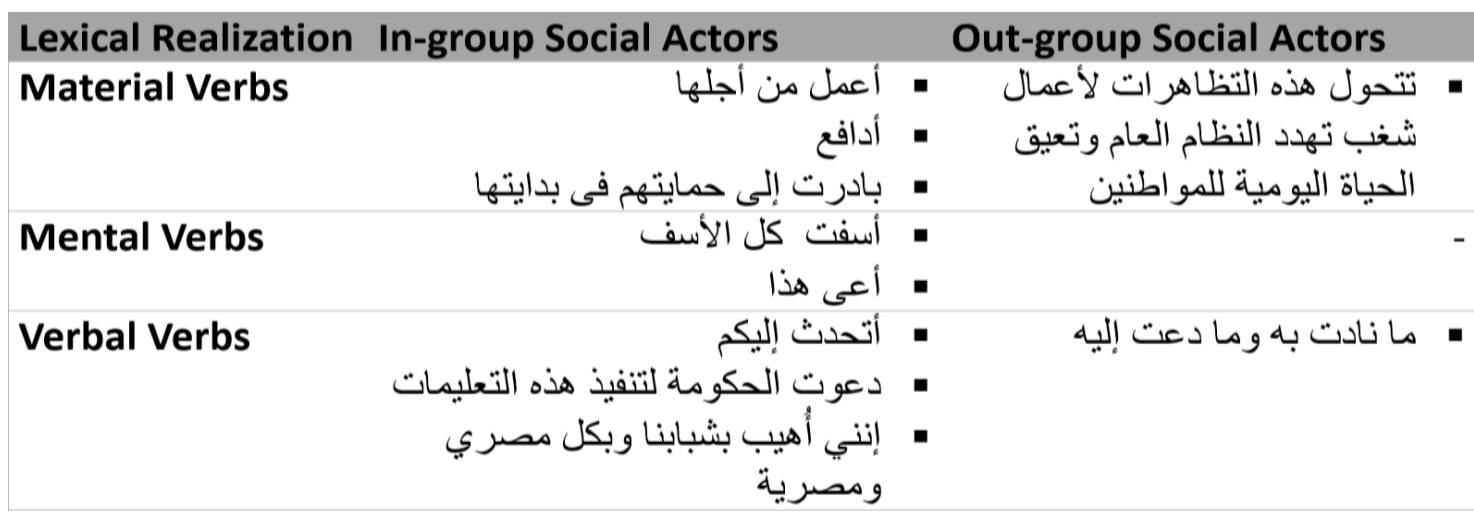

The social actor of the in-group verbs is Mubarak, and all the material verbs highlight his role in protecting the country and the protestors. His sorrow for the lives lost is revealed through

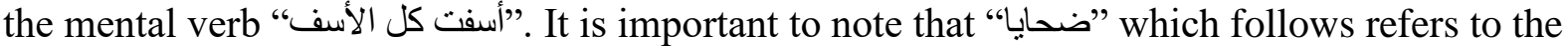
police forces and the protestors though they do not belong to the same group. This is further asserted by the mental verb "أعى هذه النطلعات المشرو عة للشتعب "which legitimatizes the protestors'

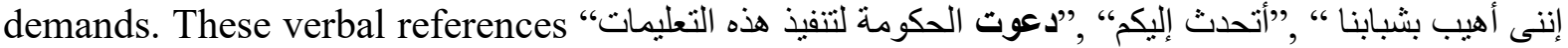

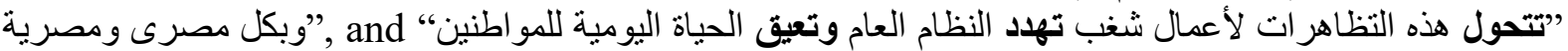
link the in-group member, Mubarak. to the protestors (out-group). These examples present Mubarak as a political leader and blame the protestors for any emerging acts of violence.

The previous nomination strategies involve predication strategies which ascribe

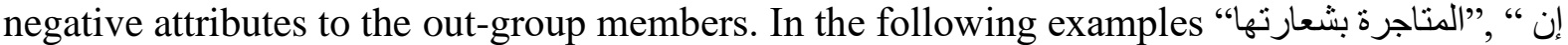
لن تصنعه الفوضى و إنما يحققه “، ",اللجوء إلى العنف"، ,"منزلقات خطيرة"، ,"خيطا رفيعا يفصل بين الحرية والفوضى

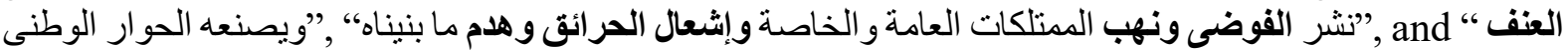
"و الفوضى والتدمير والتخريب "correlates the protests with chaos and anarchism. The contrast between "الحوار الوطنى" associates chaos with protests and ensures that the positive attributes of self-control and peace are associated with the in-group to blame the protestors for the status quo.

The speech's argumentation scheme also stresses Mubarak's authority:

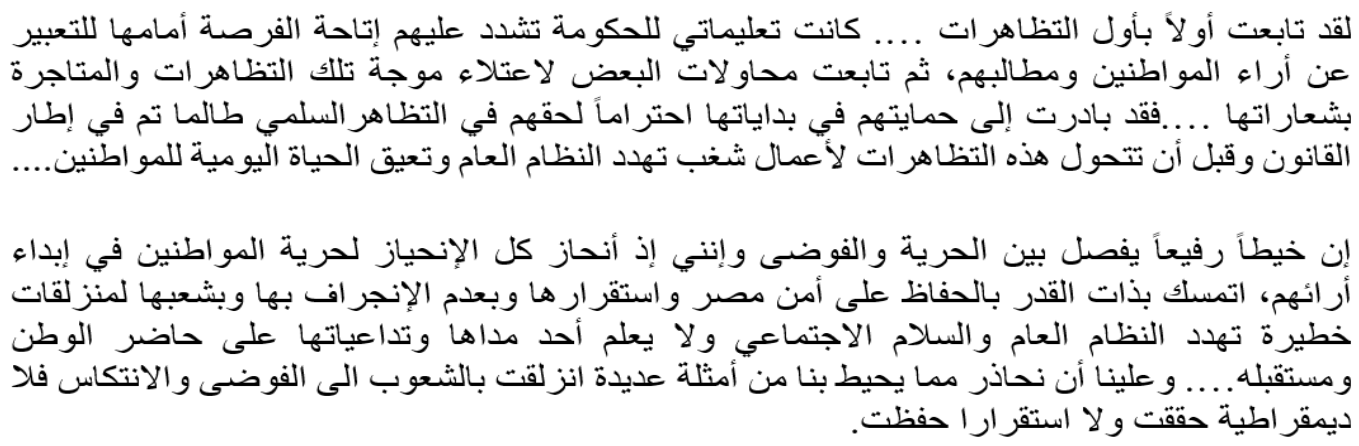

This extract relies on a blend of the topoi of authority and advantage where Mubarak's capacity imposes certain measures to contain the situation. His authority empowers him to declare that the protests are no longer peaceful, thus legitimatizing any violent action taken by the in-group.

Besides, the protests and the protestors as out-group social actors are depicted in the extract via the presupposition " which suggests that the future of the protests is unpredictable. Nevertheless, the allusions to the Tunisian 


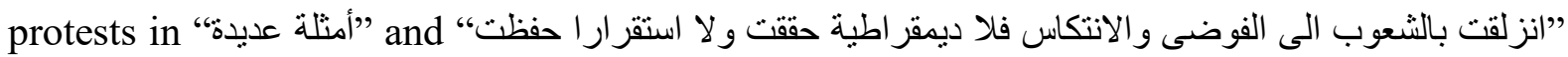
create an analogy between Tunisia and Egypt to propose that the Tunisian chaotic scenario could happen in Egypt. These predication strategies create an ad baculum fallacy as they terrorize the citizens so that they reject the protests for fear of anarchism.

The previous topoi are recurrent in Mubarak's announcement of the reform measures taken to control the situation:

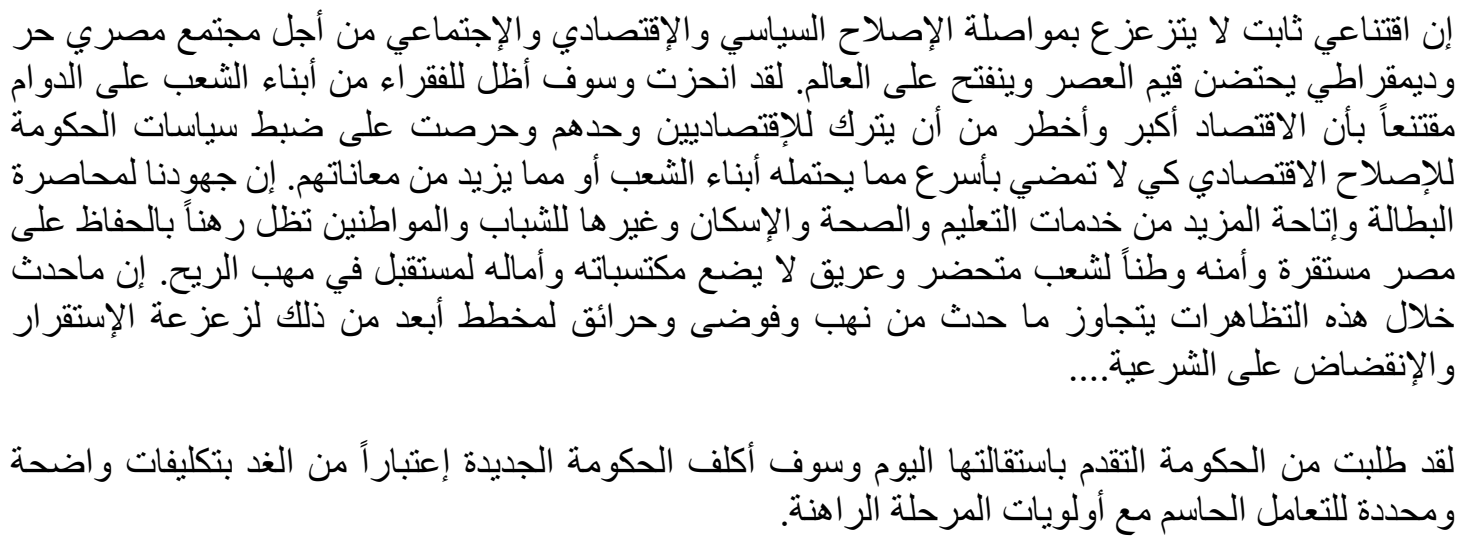

Mubarak assures his continuous support of the poor via several political, economic, and social reform measures to improve their standard of living. Economy is Mubarak's major concern as indicated by the superlative form "الاقتصاد أكبر وأخطر من أن يترك للإقتصاديين وحده". However, the ad verecundiam fallacy gives him as a president the authority to impose his will over the economists.

\subsubsection{Analysis of Mubarak's Speech on February $10^{\text {th }}$}

The last speech occurred on February $10^{\text {th }}$ before Mubarak's step down. Mubarak expressed his sorrow for the current situation and the deaths. He called the young protestors for a dialog to reach a compromise. He also referred to the formation of a constitutional committee to make the necessary constitutional changes demanded by the protestors. $\mathrm{He}$ pledged that he would protect Egypt against any internal or external threat till the last day of his life.

The social actors of the speech construct the in-group and the out-group as shown in the table below:

Table 3

Social Actors of Mubarak's $2^{\text {nd }}$ Speech.

\begin{tabular}{|c|c|c|c|}
\hline $\begin{array}{l}\text { In-group } \\
\text { Social Actor }\end{array}$ & $\begin{array}{l}\text { Linguistic } \\
\text { Realization }\end{array}$ & $\begin{array}{l}\text { Out-group } \\
\text { Social Actor }\end{array}$ & Linguistic Realization \\
\hline \multirow[t]{2}{*}{ Mubarak } & $\begin{array}{l}\text { Personal reference: } \\
\text { كرئيس للجمهورية، حسنى مبارك }\end{array}$ & Protest & 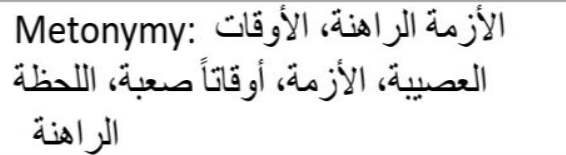 \\
\hline & & Protestors & 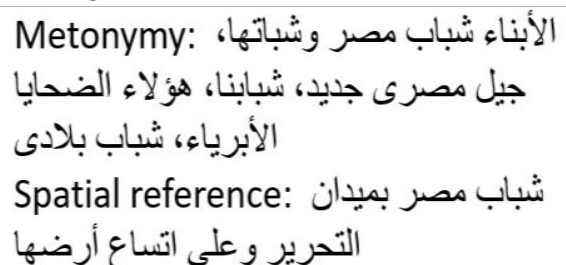 \\
\hline
\end{tabular}


The sole in-group social actor is Mubarak who directly refers to himself by his name " حسنى "مبئيس للجمهورية" "and position". These nomination strategies are significant because they defy the protests' demand of stepping him down. In contrast to himself, Mubarak uses several metonymies outlined in Table (6) to refer to the protests and protestors. The reference " شباب "مصر بميدان التحرير associates the protestors with their spatial location where the protest first started.

The construction of the social actors gets clearer upon examining their verbal realization:

Table 4

Lexical Realization of Mubarak's $2^{\text {nd }}$ Speech

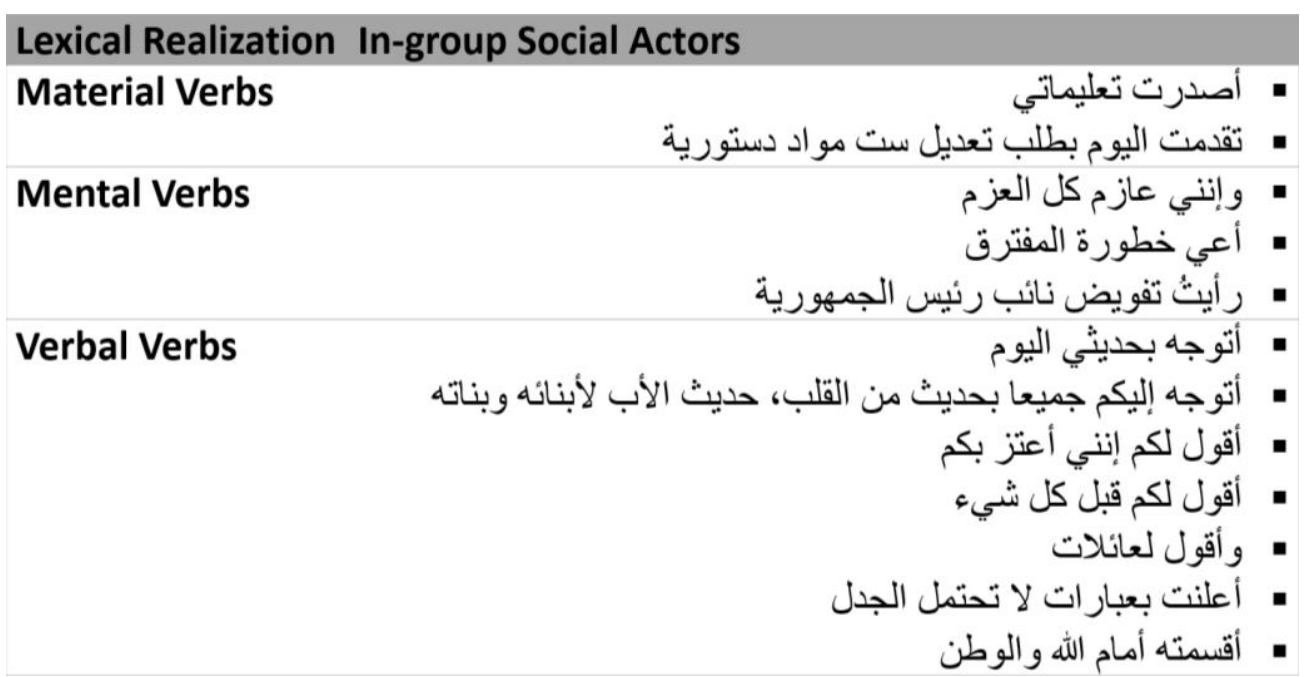

Though the out-group is the reason behind this speech, the in-group social actor is heavily represented. The verbal lexical choice of "أتوجه" is only used when Mubarak addresses the

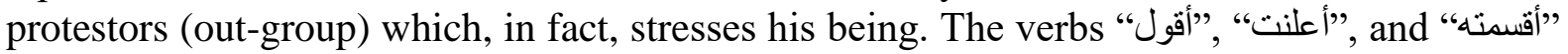
are used to address the nation whether the protestors and their families, or the entire population.

The material verbs accentuate Mubarak's capacity, especially, after the protestors announced the delegitimization of his authority. "أصدرت تعليماتى" emphasizes his power and control over the situation, especially, after the Battle of the Camel which resulted in the death and injury of many protestors. The material verb "تقدمت" discusses his compliance to the protesters” demands. The mental verbs -" emphasize his pledge to support the protestors and their demands.

Furthermore, the speech includes several predication strategies which describe the social actors. Mubarak uses a mild tone in addressing the protestors through the family metaphor "حديث الأب لأبنائه وبناته" in which Mubarak is the father and the protestors are his sons and daughters. The mental verb "العتز بكم رمز الجيل مصري جديد" supports the family image where the father is proud of his offspring who are Egypt's new generation. Their voice is heard in "يدعو إلى التغيير إلى الأفضل" where the verbal process correlates with their protest which seeks " presuppose that the father (Mubarak) is more knowledgeable and experienced than his children (protestors) with regards to Mubarak's view of the events.

In contrast to the intimacy suggested by the previous image, Mubarak uses the secondperson plural pronoun "إن دماء شها ائكم وجرحاكم لن تضيع هدر "to introduce the protestors as the outgroup. This out-group includes the families of protestors: 


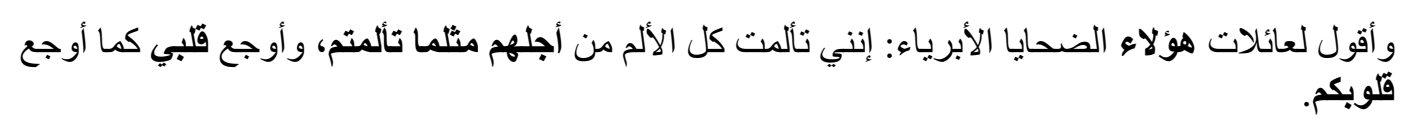

The simile " مثلما تألمنتم" puts his agony and theirs on equal footing, but " لهو لاء" and the dichotomy

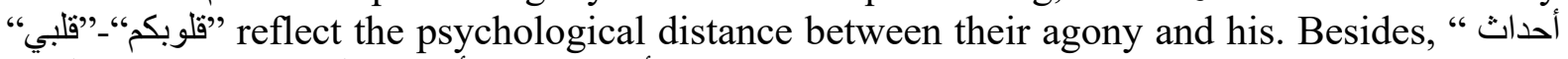
"مأساوية حزينة أوجعت قلوبنا وهزت ضمير الوطن is a metonymy referring to the Battle of the Camel which occurred on February $2^{\text {nd }}, 2012$ when two men on horses dispersed the protestors; it ended in 11 deaths and 600 injuries.

After the Battle, protestors grew angrier and held Mubarak and his supporters accountable for it. Many of them called Mubarak to step down and declared that his political regime lost its legitimacy. These conditions bring the topoi of advantage, authority, and burdening together:

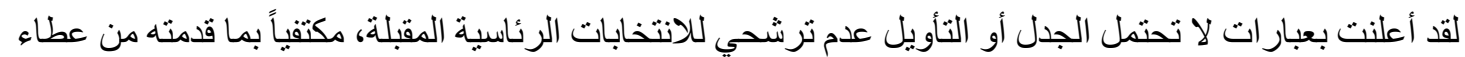

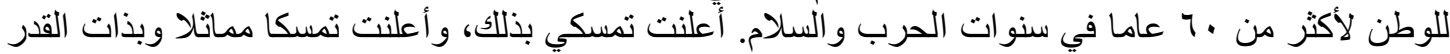

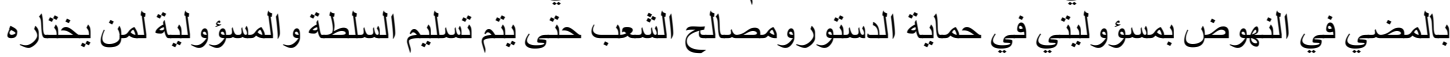

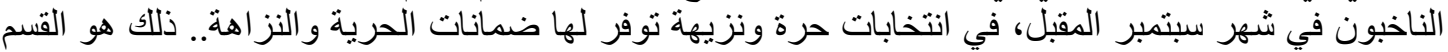

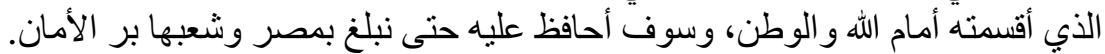

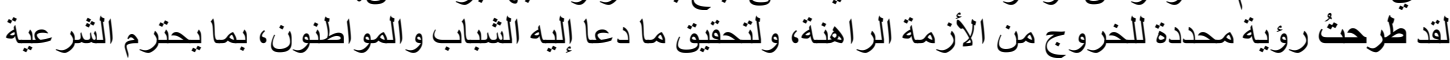

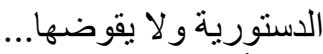

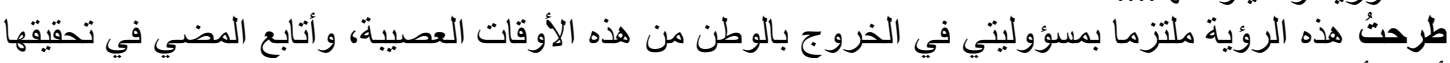

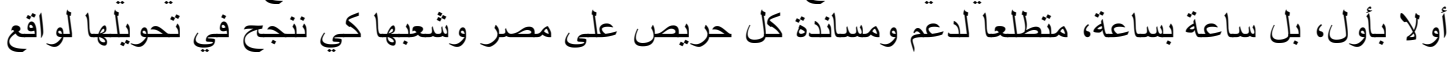

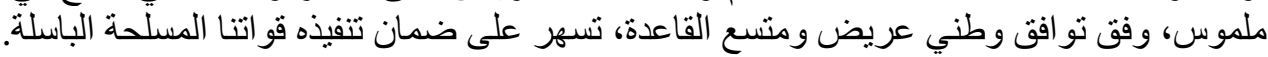

Mubarak is determined to use his current authorial powers as a President in "بمسؤوليتي", "و المسؤولية" to direct the demands of the protestors. Each time "طرحما" is used, a condition to resolve the situation is revealed. This authorial power entails the topos of burdening and advantage where Mubarak -the Egyptian President- has the task of saving the nation.

Mubarak also alludes to his service during the 1973 War in the Egyptian armed forces

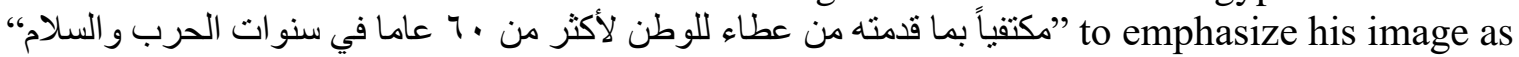
the hero of peace and war. This allusion occurs within the topos of history:

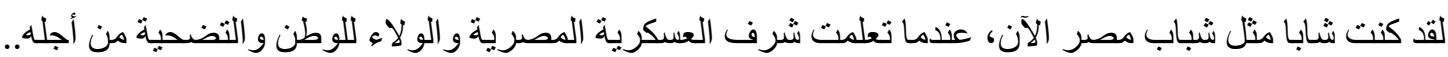

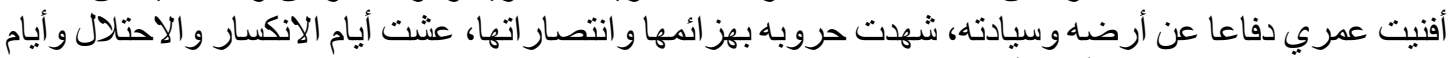

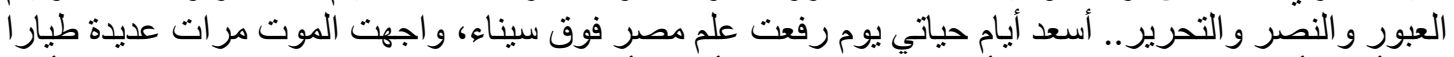

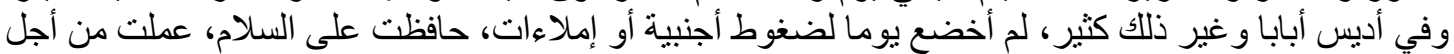

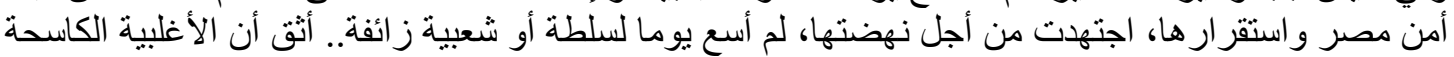

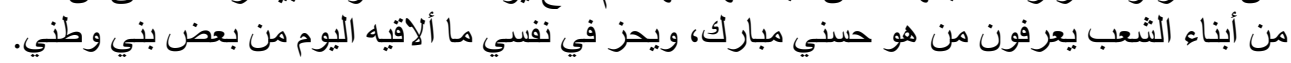

It establishes an analogy between his youth and the protestors' to highlight the positive selfand negative other-presentation. As an in-group member, Mubarak sacrificed his life to serve his country in times of war and peace whereas the protestors are dragging the country he saved towards unknown consequences of riot and anarchism.

The analogy continues when he mentions that he does not allow any external force to dictate him what to do " لم أخضع يو ما لضغوط أجنبية أو إملاءات unlike the protestors who allow others to direct their will:

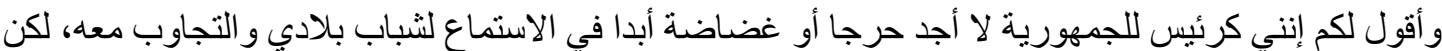

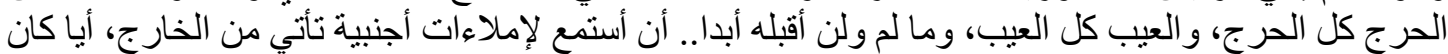

$$
\begin{aligned}
& \text { مصدر ها و أيا كانت ذر ائحها أو مبرر اتها. }
\end{aligned}
$$


The previous excerpt includes a straw man fallacy in which Mubarak defames the protestors' cause and demands by alluding that the protestors' demands are not originally theirs as they are imposed by external wills which target at destabilizing Egypt. This fallacy urges the masses to suppress the protestors and helps his to gain their cheers. In addition, Mubarak uses the ad misericordiam fallacy to win people's support in the reference to the dangers he faced during و واجهت الموت مر ات عديدة طيار اوفي أديس " his service in the armed forces and tenure as a President in ويحز في نفسي ما " أبابا " وال ألاقيه اليوم من بعض بني وطني "which portrays the Egyptian protestors as ungrateful to his sacrifices.

\subsection{Analysis of Hariri's Speeches}

Lebanon suffered from several economic issues which deteriorated in the wake of the new tax measures imposed on October $17^{\text {th }}, 2019$. It led tens of thousands of citizens to protest peacefully in many cities across the country against the government on October $18^{\text {th }}$. The Lebanese protestors called for social and economic reforms, and the government announced a few reforms; however, the protests continued and lasted for thirteen days. The Lebanese Prime Minister, Saad Hariri, addressed the nation to avoid the escalation of the situation. He held a press conference on October $21^{\text {st }}$ and made two speeches on October $18^{\text {th }}$ and October $29^{\text {th }}$. It is important to note that Hariri's speeches were delivered in colloquial Lebanese accent and dialect. This section is devoted to the analysis of Hariri's two speeches to identify his account of the Lebanese Revolution.

\subsubsection{Analysis of Hariri's Speech on October $18^{\text {th }}$}

After the beginning of the protests in Lebanon, the cabinet scheduled a meeting on Friday, October $18^{\text {th }}, 2019$ which was cancelled for security issues. Hence, Hariri made his first televised speech to the nation from the Grand Serail, the headquarters of the Prime Minister on the second day of the protest. The twelve-minute-speech discussed the reasons behind the protests and the legitimation of people's anger. It also stressed that lack of cooperation between the different parties of the government hindered the path of reform Hariri proposed. The speech concluded by giving the government 72 hours to cooperate with him and suggest corrective measures.

The social actors defined in the speech construct two groups: the in-group and the outgroup. The table below reveals that the in-group includes the Hariris and his allies whereas the rest of the parties involved in the protest form the out-group as demonstrated in the table below:

Table 5

Social Actors of Hariri's $1^{\text {st }}$ Speech.

\begin{tabular}{|c|c|c|c|}
\hline \multicolumn{2}{|c|}{$\begin{array}{l}\text { In-group Social Linguistic Realization } \\
\text { Actor }\end{array}$} & Out-group Social Actor & Linguistic Realization \\
\hline The Hariris & 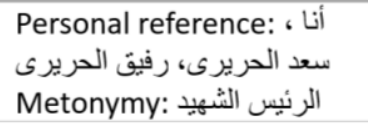 & The Nation & 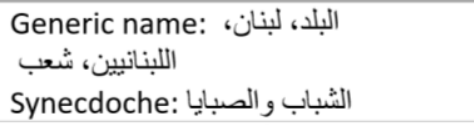 \\
\hline \multirow[t]{3}{*}{ Allies } & $\begin{array}{l}\text { Direct reference: مؤتمر } \\
\text { أشقائنا، أصدقائنا : بلمجنمع الدولى } \\
\text { Metonymy }\end{array}$ & Protest & 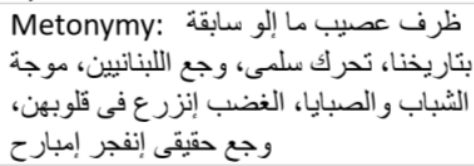 \\
\hline & & Protestors & 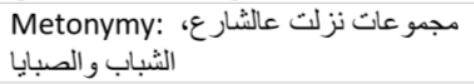 \\
\hline & & Cabinet & 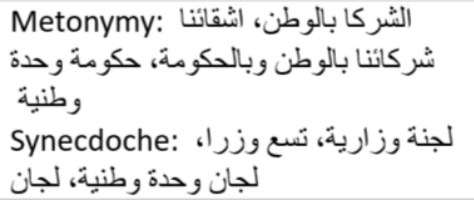 \\
\hline
\end{tabular}


The main social actor of the in-group is the descendants of the Hariri family, Saad Hariri and his late father Rafik Hariri, whose names are mentioned in the speech. The speaker, besides, refers to himself using the personal pronoun "أنا". The second social actor in this in-group is Saad Hariri's allies. All through the speech, there are indirect references to this ally as "أشقائنا" and " before the direct reference of " مؤتمر سيدرقائنا بالمجنمع الدولى". CEDRE is a conference held in Paris in support of Lebanon's development and reform. The participating countries approved to give Lebanon a fund worth 11 billion dollars to implement economic reform measures. As the conference hosted some Arab countries, "أشقائنان" is used to name them whereas “"صدقائنا بالمجتمع الدولى" refers to the international countries.

The out-group includes the nation, protests, protestors, and cabinet. Lebanon is named using several generic names: “البلد" "شعب" "اللبنانيين", and the specific name "لبنان", Hariri's speech uses various metonymic expressions to name the protests and the protestors. With regards to the protests, the predication strategies cannot be separated from the nomination as the interrelation between them reflects Hariri's view of the situation. Some of the metonymies referring to the protests are somehow negative such as " عصيب ما " which is described as "طرف "إلو سابقة بتاريخنا " Hariri also refers to the protests as "الغضب" which is implemented in the heart of the Lebanese, "إنزرع فى قلوبهن", to demonstrate that there is another power directing the "وجع حقيقى إنفجر إمبارح" "و where "إنفجر" denotes the eruption of anger and destruction.

The last social actor in the speech is the cabinet. Hariri is the Prime Minister of a coalition government representing the various religious and political sects in Lebanon. The

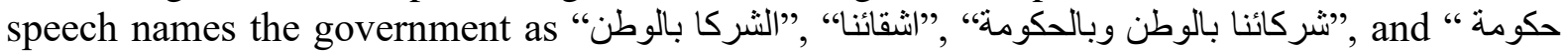
"وحدةوطنية It appears from these names that the government is cooperative, yet the synecdoches

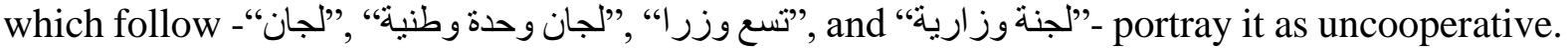
Hariri clarifies this by mentioning that each and every proposal he submitted to the government was discussed in several emerging committees which hindered the implementation of reforms; this delay resulted in the anger of the Lebanese.

The lexical items used in this speech contribute to the construction of the in-group and the out-group as they clarify Hariri's perspective of the social actors. The following table introduces the most significant lexical items employed in the speech:

Table 6

Lexical Realization in Hariri's $1^{\text {st }}$ Speech.

\begin{tabular}{|c|c|c|}
\hline Lexical Realization & In-group Social Actors & Out-group Social Actors \\
\hline Material Verbs & 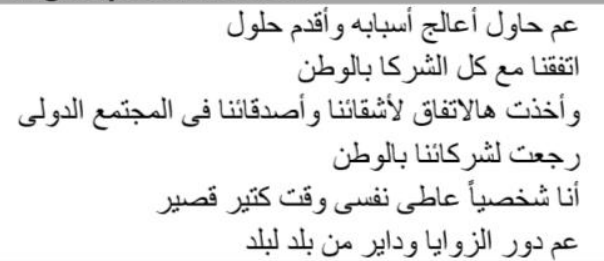 & - \\
\hline Mental Verbs & 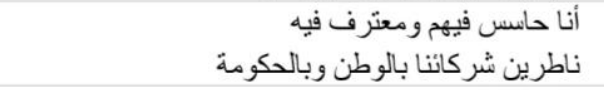 & . \\
\hline Verbal Verbs & 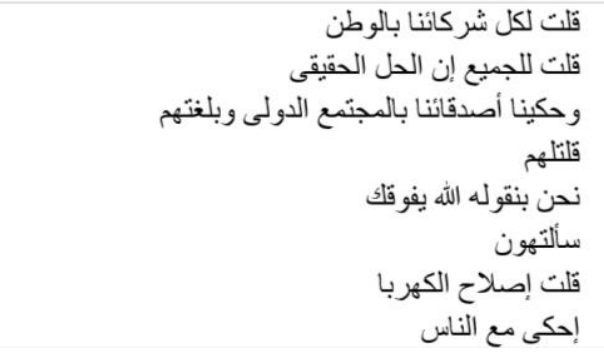 & 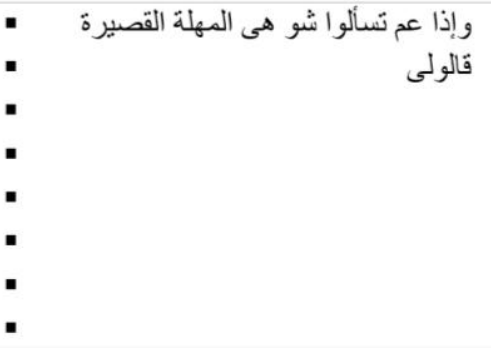 \\
\hline
\end{tabular}


With regards to the lexical choices, the speech focuses on the representation of the in-group rather than the out-group in order to blame the rest of the social actors. The only social actor underscored in the out-group is the protestors whose feelings are not represented or stressed unless in metonymies. The material verbs " anjلو " anclude the protestors. Performing these actions, clashes would take place between the protestors, and the army and security forces. As for the verbal representation of the protestors, it is only found at the very end of the speech -"تسألو ا" where they wonder about the grace period Hariri considers.

The in-group lexical realization of Hariri as a social actor tends to be verbal whenever he refers to his political partners in the government. He gives force to his actions by the verbal choices. The use of this type of verbs becomes very significant when Hariri mentions what

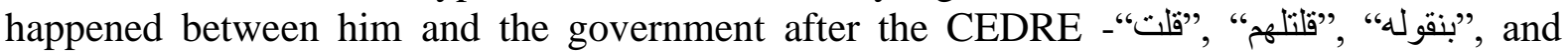
"وحكينا" and "و "و بلغتهمه" These verbs are preceded by reveal that he exerted effort to negotiate at the CEDRE with the international community to generate funds for the country.

Hariri depicts himself as a proactive leader and a state man as evident in the material

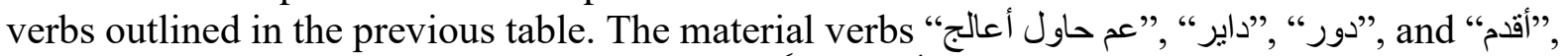
in addition to the nominal structure "أنا شخصياً عاطى نفسى" highlight his active role in achieving the economic reform to avoid people's rage. "و "وأخذى عاطن "refers to his travel to Paris for CEDRE where he sought fund for Lebanon. His keenness on involving the government and seeking its approval on his achievement is expressed by the material verb "رجعت". These material verbs stress his strenuous efforts in improving the economic conditions of the country.

With regards to the mental verbs, Hariri expresses in the nominal structure " أنا حاسس "فيهم ومعترف فيه of the government. This is further ascertained by "ناطرين" which underscores the government's indifference. The interrelation between these three types of lexical items juxtaposes Hariri's proactive approach in handling the crisis to the government's lax attitude.

The references to the protests constitute the predication strategies of the speech. In the beginning, Hariri stresses that he has always been honest in discussing any situation before the nation. In the clause "رغم كل شى كنا بعدنا حنبقى عيلة واحدة اسمها لبنان", Hariri stresses that the protests will not tear the nation apart. "عيلة واحدة "establishes some sort of intimacy between Hariri and the people as they are family members. This closeness changes when the metaphors describing the protest denote anger and violence. In the following examples "هالوجع إنفجر إمبارح فى الثنارع", "عم يعبرو ا عن الغضب بالثار ع اليوم" "وجع حقيقى إنفجر إمبارح"، "كيف الغضب إنزرع بقلوبهم يوم بعد يوم"، and", Hariri repeats "إنفجرم " to instill fear and emphasize the uncontrollability of the protests.

Moreover, metaphors portray the out-group, especially, the cabinet. The following metaphor is taken from football: "لكن الكل قاعد مرتاح على وقته و همه كيف يسجل نقاط بملاعب الآخرين". " stands for the uncooperative members of the government who do not support Hariri's reform path. They are not performing their duties towards the nation, yet they are concerned with highlighting other people's mistakes. In the second metaphor, Hariri reveals his sacrifice

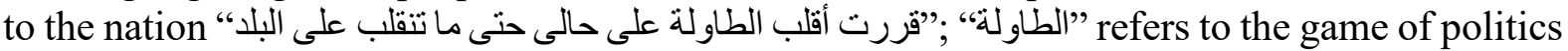
which Hariri is willing to lose to protect his country from any potential threat. These metaphors are supported by the repetition of the temporal references " إمبارح" which refers to the beginning of the protest and "لاليوح" which stands for October $18^{\text {th }}$ to contrast his willingness to protect his nation with the indifference of the government.

It is worth mentioning that Hariri's speech tackles various interrelated topics: infiltration with foreigners and non-patriotic entities, threats to the national security and the 
economy, and increase in unemployment rate. Certain topoi are used to persuade the Lebanese of the validity of his arguments. The topos of numbers is used in the beginning of the speech:

$$
\begin{aligned}
& \text { الكهربة بتكلف الدولة مليارين دو لار بالسنة وسلسلة الرتب و الرو اتب صارت وملتزمين فيها لكن تبين إنه فاقت }
\end{aligned}
$$

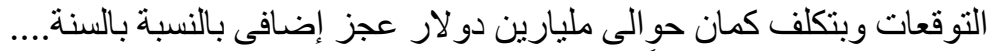

$$
\begin{aligned}
& \text { وو افقو ا مشكورين إنه بناءاً على هالإصلاحات ياللى نحن مقررينها يلتزموا بحداشئ بلثر مليار دولار لتمويل هالحل... }
\end{aligned}
$$

It informs the citizens about the budget deficit and how Hariri solved this issue. Hariri uses the topos of burdening as well to show his concern about the economic reform:

$$
\begin{aligned}
& \text { بلثنا من تشكيل الحكومة أسابيع و أثشر وفصول. قلت إصلاح الكهربا لأن الكهربا وحدها بتمثل مليارين دو لار }
\end{aligned}
$$

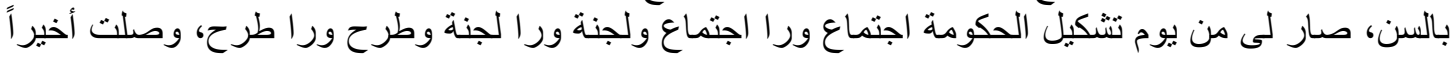

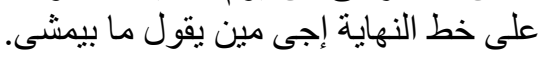

ما ضل فى مماطلة، ما ضل فى فركوشة مانحطت " The previous topoi include the straw man fallacies " and "و جهى " which depict the government members as irresponsible; they do not cooperate with him to resolve the situation. Hence, he blames them for the eruption of the protests because they hurdled his reform path.

Furthermore, the topos of history is employed when Hariri compares the status quo to the conditions during his father's tenure:

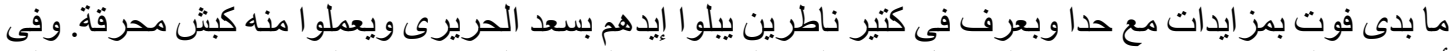

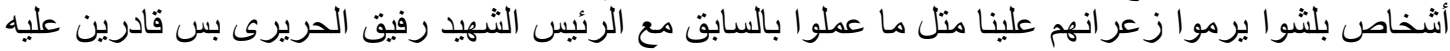

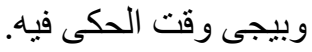

The predication strategies of the metaphor "يبلوا إيدهم بسعد الحريرى" alludes to the assassination of Saad's father, Rafik Hariri; the metonymy "الرئيس الثهيدي" is also used to refer to Rafik Hariri. It is important to note that the latter was a leading Lebanese politician who was assassinated in a truck bombing. The adjective "الثهيد" to label Rafik Hariri creates an ad misericordiam as he creates an analogy between his destiny and his father's. This is further emphasized via the metaphor "كبش محرقة" in which he clearly mentions that his opponents would sacrifice him for the government's failure to achieve any reform.

Hariri ends his speech with topoi of threat and advantage for the government members in case they remain uncooperative:

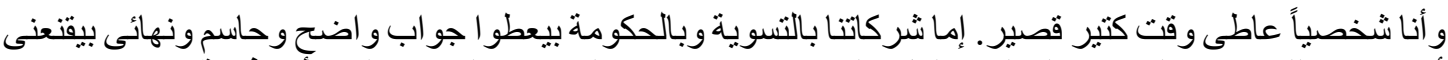

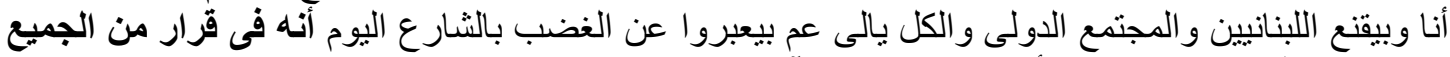

$$
\begin{aligned}
& \text { للإصلاح ووقف الهلار والفساد أو بيكون إليّ كلام آخر. }
\end{aligned}
$$

Hariri instills fear in his opponents (the social actor of the out-group) to resolve the situation they caused. These topoi include an either-or fallacy when Hariri offers two options only for them: Either they take action, or it would be Hariri's call. The negative representation of the protests promotes the ad baculum fallacy recurrent in the following examples: "ويمكن ينقال إن فى"

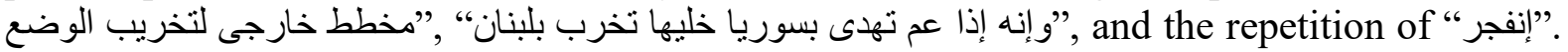
Hence, the Lebanese will blame the protestors for the deterioration of Lebanon's economy and sympathize with Hariri who is Lebanon's hero and savior.

\subsubsection{Analysis of Hariri's Speech on October $2^{\text {th }}$}

Hariri announced suggested reform measures on October $21^{\text {st }}$ to appease the protests; nonetheless, the government did not cooperate on implementing them. As Hariri's negotiations with his political partners failed, he decided to resign. In a brief speech that lasted for two minutes and ten seconds, televised from his palace on Tuesday October $29^{\text {th }}$, Hariri addressed 
the nation. In the speech, Hariri stated that his negotiations with the cabinet reached a deadlock; thus, he would head to the presidential palace in Baabda to submit the resignation to the Lebanese president. He also called the citizens to control their rage and protect the peace and security of Lebanon and urged his political partners to protect their nation.

The speech, via nomination strategies, divides the social actors into an in-group and an out-group as clarified in the table below:

Table 7

Social Actors of Hariri's Last Speech.

\begin{tabular}{|c|c|c|c|}
\hline $\begin{array}{l}\text { In-group } \\
\text { Social Acto }\end{array}$ & Linguistic Realization & Out-group Social Actor & Linguistic Realization \\
\hline \multirow{4}{*}{$\begin{array}{l}\text { Social Acto } \\
\text { Hariri }\end{array}$} & $\begin{array}{l}\text { Personal reference: أنا الحكومة: Metonymy } \\
\text { أنا }\end{array}$ & Protest & $\begin{array}{l}\text { Metonymy: الأزمة، بهاللحظة التاريخية } \\
\text { التخية }\end{array}$ \\
\hline & & Protestors & 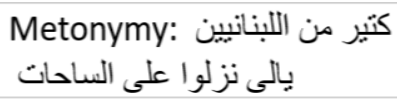 \\
\hline & & The Nation & 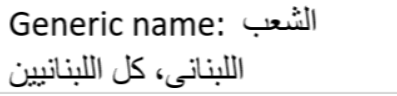 \\
\hline & & Cabinet & $\begin{array}{l}\text { Metonymy: الشركاء بالحياة السياسية } \\
\text { السياة }\end{array}$ \\
\hline
\end{tabular}

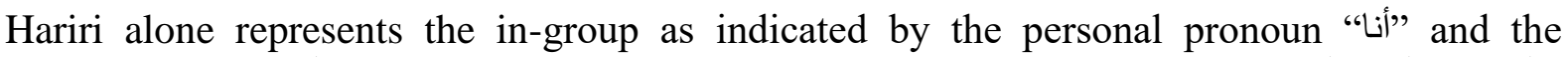

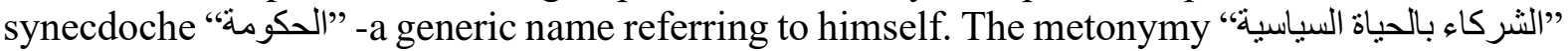
represents the rest of the cabinet as the out-group; this metonymic expression is ironic as the negotiation with "الثركاء" failed and ended in resignation. Therefore, the synecdoche and the metonyms suggest that there are two conflicting groups within the cabinet.

The speech acts as a message for the Lebanese people as indicated by the nomination strategies. The generic names "الثعب اللبنانى" and the second-person plural pronoun "بخفيكم" refer to the Lebanese people whereas any direct reference to the protests or the protestors is absent. Metonymies are also used to refer to these social actors. The protests are described as " الأزمة" and "كثير من اللبنانيين يالى نزلوا على الساحات" ،"بهاللحظة التاريخية" is used for the protests and the protestors; the usage of the quantifier "كتير" justifies as to why Hariri resigns to the will of the protestors.

Despite its brevity, the verbs are worth exploration as they contribute to the construction of the in-group and out-group:

Table 8

Lexical Realization of Hariri's Last Speech.

\begin{tabular}{|c|c|c|}
\hline Lexical Realization & In-group Social Actors & Out-group Social Actors \\
\hline \multirow[t]{5}{*}{ Material Verbs } & وصلت لطريق مسدود & 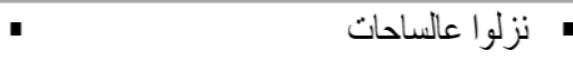 \\
\hline & صار لازم نعمل صدمة & كيف نحمى لبنان ونمنع وصول أى حريق \\
\hline & أنا طالع على قصر بعبدا & لإله \\
\hline & تقديم استقالة & - \\
\hline & استقالتى بحطها بتصرف & - \\
\hline Verbal Verbs & ولكل الشركاء بالحباة السباسبة بقول & ل لبطالبو ا بالتغيير \\
\hline & و وأنا كمان بقول ما في حدا أكبر من & - \\
\hline
\end{tabular}


As shown in Table (8), the speech heavily relies on material verbs which focus on the actions of the in-group and out-group. The main social actor of the in-group is Hariri who refers to himself by the first-person singular pronouns attached to the verbs " which reveal his frustration. The material verb "نعمل" prepares for the action "صدمة" to underscore how massive the decision is. Referring to the submission of the resignation, Hariri employs two different structures: "تقديم" "أنا طالع" The nominal sentence "أنا طالع" stresses the physical effort of moving from his palace to Baabda while the infinitive "تقديم" indicates to the resignation.

The out-group includes the protestors and the Lebanese politicians. The first material verb "refers to the protestors; the referent of the third-person plural pronoun attached to the verb is the protestors, shown by "كتير من اللبنانيين". In the second material verb, Hariri tackles the responsibilities of the Lebanese politicians; nonetheless, the first-person plural pronoun "نحمى" and "نمنع "involves Hariri in them despite the resignation. In contrast to the material verbs, there are not many verbal choices. Hariri uses "بقول" twice in the speech. The first instance is when he dictates the responsibilities of the Lebanese government. When he expresses that the motherland is the most precious thing in life, "بقول" is used again to make his statement more forceful.

The predication strategies used in the speech bring the three social actors together: Hariri, the Lebanese citizens, and the political partners. In the beginning of his speech, he uses the metaphors "وصدمة كبيرة" where the former stands for the uncooperative government, and the latter refers to the resignation. The adjectives " مسدود" and "كبيرة" reveal the cause-effect relationship between the two metaphors as the deadlock resulted in the resignation. In the conclusion of his speech, the superlative form "ما فى حدا أكبر من بلدهاه gives supremacy to the nation over any authority which is further reinforced by " استقالتى بحطها بتصرف فخامة الرئيس وكل اللبنانين".

The whole speech is dominated by the topoi of burdening and advantage which urged Hariri to resign:

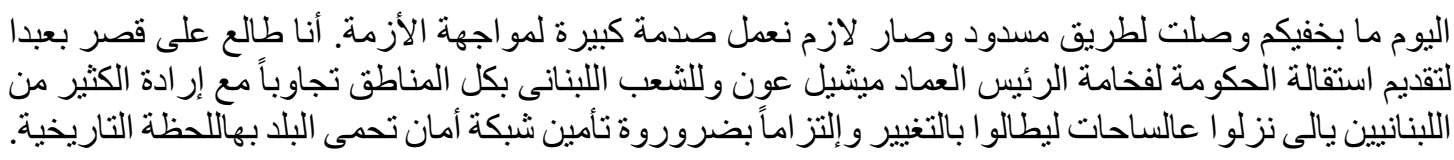

As per his capacity as the Prime Minister, Hariri found himself responsible for resolving the situation. Therefore, he imposed on himself the duty of responding to the will of people:

$$
\text { من اللبنانيين التقالة الحكومة لفخامة الرئيس العماد ميشيل عون وللثعب اللبنانى بكل المناطق تجاوباً مع إرادة الكثير }
$$

This topos portrays him as the savior; it also includes the ad verecundiam fallacy “ الرئيس العماد "which gives the impression that the Lebanese people have the same authority as the president though this is untrue. Following Hariri's announcement, the citizens cheered in the streets, yet the Lebanese President negotiated with Hariri to remain in power that he broke the constitutional laws and did not assign a new cabinet.

Besides, the ad mesericordiam fallacy is seen in his claim that his resignation will protect the country “إلتزاماً بضروروة تأمين شبكة أمان تحمى البلد بهاللحظة التاريخية". It expands on his image as a savior for the country and triggers people's empathy with his situation and sacrifice. In line with his image as a savior, he is the scapegoat of the out-group represented in the protestors and the political partners, especially, that he relinquished his powers to preserve his country's security and stability. 
The topoi of burdening and advantage control the second part of the speech which is directed to the political partners:

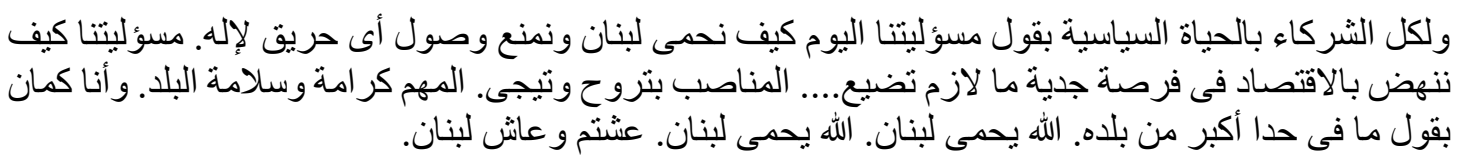

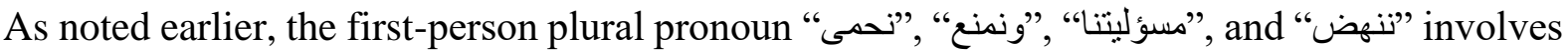
Hariri in the political sphere despite his resignation. Not only does he assign himself a duty in protecting the country, but he also dictates the active politicians their duties. The whole topos is based on the ad mesericordiam fallacy where Hariri is the savior and scapegoat even after resigning as a Prime Minister.

The topos of advantage which focuses on the advantage for all in "المناصب بتروح وتيجى" gives prominence to the state over any position. It underscores Hariri's sacrifice for the stability of the nation. Besides, the topos of comparison "ما فى حدا أكبر من بلده" where the superlative form compares him to the nation to contribute to the savior and scapegoat image. Finally, the repetition of "instills fear as it shows that Lebanon is under the threat of protests which is further illustrated by his call to the Lebanese " ندائى لكل اللبنانيين إنهم يقدمو مصلحة لبنان "وسلامة لبنان وحماية السلم الأهلى ومنع التدهور الاقتصادى على أى شى أخر in which he indirectly blames the protestors for any potential harm which might occur. All these examples portray an image of the savior Hariri who is the scapegoat for protestors' demands and the stability of Lebanon.

\subsection{Conclusion}

This paper examined selected speeches for the former Egyptian president, Mubarak, and the former Lebanese Prime Minister, Hariri during the Egyptian and Lebanese protests. Three DHA discursive strategies - nomination, predication, and argumentation- were analyzed to reveal how the social actors are categorized into in-group and out-group. It is noted in the analysis that the nomination and predication strategies are intertwined in the creation of the US/THEM dichotomy. The nomination strategies identify and classify the social actors into an in-group where US refers to the politicians and their supporters and an out-group where THEM refers to the protestors and the protests. This is linguistically established by tropes (metonymies and metaphors), membership categorization devices (personal references and generic names), and lexical categories (verb types).

The predication strategies categorize the presentation of the social actors via positive and negative attributes. Across the studied speeches, Mubarak and Hariri assign positive traits for themselves and the social actors of their in-group because they are aligned with them. Nonetheless, the negative attributes of chaos, riot, violence, and anarchism are ascribed to the out-group. In addition, the allusions to previous similar events establish an analogy between the current situation and previous ones to emphasize the positive self- and negative otherpresentation.

The analysis also reveals an overlap between some of the topoi and fallacies used by Mubarak and Hariri. They used the topoi of history, advantage, burdening, and authority. The topos of history reminds the citizens of their leaders' legacy and sacrifice for the sake of the nation. Across the four speeches, this topos entails the ad misericordiam fallacy in which Mubarak and Hariri blame their nations for the chaos stirred by the protestors and their disappointment to win the nation's support and end the protests.

The topoi of advantage and burdening reveal that the political leaders toiled to protect their people and their interests against any threat emerging from the protests and the enemies 
of the state. The image of the savior and scapegoat springs in the speeches from the topos of burdening which leads to the topos of advantage in which the politician makes decisions for the advantage of all the citizens. These topoi include the fallacies of ad baculum and ad misericordiam which instill fear and guilt in the masses' hearts and ad verecundiam where impersonal and personal authorities are revealed even though these politicians' failure caused the protests.

The integration of these three discursive strategies promote the interrelation between historical events and political field in which the discursive event is embedded. The US/THEM dichotomy reveals the speaker's (US) prejudice against the addressees (THEM). The discourse of politicians shows the US as saviors of their countries seeking the stability of nation via their ruling. They, as social actors, have power, establish the system, and protect the citizens' right for protest while preserving the law. THEM are the out-group who are inexperienced and naiive. Finally, the speeches' account of these events reconstructs the protests on the global and local arenas where US dominates THEM.

\section{References}

Al-Arabiya. (2019, Oct.). Al-Hariri Yastaqeel [Video file]. Retrieved from https://www.youtube.com/watch?v=d1JTCeE_4io

Al-Arabiya. (2019, Oct.). Kalemet Ra'ees Al-Wozara'Al-Lebnani Kamela Hawl Al-Tazahorat fi Lebnan [Video file]. Retrieved from https://www.youtube.com/ watch? $=\mathrm{tCi} 1 \mathrm{RhLH} 764 \& \mathrm{t}=7 \mathrm{~s}$

Beard, A. (2000). The language of politics. London: Routledge.

Chilton, P., \& Schaffner, C. (1997). Discourse and politics. In van Dijk, T. A. (Ed.), Discourse as social interaction (pp. 206-31). London: Sage.

Reisigl, M., \& Wodak, R. (2001). Discourse and discrimination: Rhetorics of racism and antisemitism. London: Routledge.

Wodak, R. (2001). The discourse-historical approach. In R. Wodak \& M. Meyer (Eds.), Methods of critical discourse analysis (pp. 63-94). London: Sage.

Wodak, R. (2006). Mediation between discourse and society: Assessing cognitive approaches in CDA. Discourse Studies, 8(1), 179-190.

Wodak, R. (2009). The discourse of politics in action: Politics as usual. New York: Palgrave Macmillan.

Wodak, R., de Cillia, R., Reisigl, M., \& Liebhart, K. (2009). The discursive construction of national identity. Edinburgh: Edinburgh University Press.

Zakeret Maspero. (2015, Dec.). Khetab Mubarak Al-Awal [Video file]. Retrieved from https://www.youtube.com/watch?v= L6rMTbxEXvU

Zakeret Maspero. (2015, Dec.). Al-Khetab Al-Akheer li Mubarak [Video file]. Retrieved from https://www.youtube.com/watch? v=9_06qCKV3bE\&t=12s 